\title{
ALIH TEKNOLOGI PENGOLAHAN PANGAN LOKAL DI KENAGARIAN ANDALEH, LIMAPULUH KOTA
}

\section{THE TRANSITION TECHNOLOGY OF LOCAL FOOD IN ANDALEH VILLAGE, LIMAPULUH KOTA REGENCY}

\author{
Prima Yaumil Fajri ${ }^{1)}$, Nela Eska Putri ${ }^{2)^{*}}$, Rilma Novita ${ }^{3)}$, Gusmalini $^{4)}$, Yenni Muchrida ${ }^{5)}$ \\ ${ }^{1)}$ Jurusan Teknologi Pertanian, Politeknik Pertanian Negeri Payakumbuh \\ email: primayaumil@gmail.com \\ ${ }^{2)}$ Jurusan Teknologi Pertanian, Politeknik Pertanian Negeri Payakumbuh \\ email: nelaeskaputri@gmail.com \\ ${ }^{3)}$ Jurusan Teknologi Pertanian, Politeknik Pertanian Negeri Payakumbuh \\ email: rilmanovita@yahoo.com \\ ${ }^{4)}$ Jurusan Teknologi Pertanian, Politeknik Pertanian Negeri Payakumbuh \\ email: gusmalinip@gmail.com \\ ${ }^{5)}$ Jurusan Teknologi Pertanian, Politeknik Pertanian Negeri Payakumbuh \\ email: elokyenni5@gmail.com
}

\begin{abstract}
ABSTRAK
Jagung banyak dibudidayakan di Kenagarian Andaleh di Kecamatan Luak, Kabupaten Limapuluh Kota. Jenis jagung yang dibudidayakan adalah jagung gigi kuda yang sering dijadikan sebagai pakan ternak terutama pakan unggas. Jagung gigi kuda memiliki biji berbentuk gigi, mengandung karbohidrat (pati) yang tinggi, dan bertekstur keras. Ciri khas jagung ini adalah memiliki biji yang melekuk di bagian tengah atau bagian atas biji. Kegiatan ini bertujuan untuk meningkatkan pengetahuan masayarakat Nagari Andaleh Kecamatan Luak, tentang pemanfaatan bahan pangan lokal, khususnya komoditi jagung ini melalui alih teknologi pengolahan menjadi nugget jagung. Kegiatan diawali dengan memberikan penyuluhan tentang praktik sanitasi, meliputi sanitasi pekerja, sanitasi peralatan, dan sanitasi pengolahan, serta cara pengolahan pangan yang baik. Nugget jagung dibuat dari campuran daging ayam dan jagung dengan perbandingan 1:0.2. Melalui kegiatan ini, masyarakat mampu menerapkan higieni dan sanitasi dalam pengolahan pangan, serta memiliki keahlian dalam pengolahan jagung menjadi produk pangan baru, yaitu nugget jagung, sehingga meningkatkan pemanfaatan bahan pangan lokal dan meningkatkan perekonomian masyarakat. Dengan alih teknologi pemanfaatan bahan pangan lokal jagung diharapkan tumbuh motivasi untuk mengembangkan usaha skala rumah tangga yang berpengaruh pada peningkatan perekonomian masyarakat di Kenagarian Andaleh.
\end{abstract}

Kata kunci: Jagung Gigi Kuda, Nagari Andaleh, Nugget Jagung, Alih Teknologi, Pangan Lokal

\section{ABSTRACT}

Corn is widely cultivated in Andaleh Village, Luak Sub-district, Lima Puluh Kota Regency. The type of corn that cultivated in this village is dent corn (Zea mays var. indentata), which often used as animal feed, especially poultry feed. Dent corn has a tooth-shaped seed, contains high carbohydrates (starch), and has a hard texture. The characteristic of this corn form is that the seeds have an indentation in the middle or top of the seed. The purpose of this programs was to increased the knowledge Andaleh Village community, Luak District, about the utilization of local food, especially dent corn through the transition technology of corn processing to be corn nuggets. The activity began with provided counseling on sanitation practices, including personal sanitation, equipment sanitation, and processing sanitation, as well as good manufacturing practice. Corn nuggets were made from a mixture of chicken and corn in a ratio of 1: 0.2. Through this programs, the community will be able to apply hygiene and sanitation in food processing, and have expertise in processing corn into new products like nuggets, thereby can increase the utilization of local foodstuffs and improve the community's economy. Transition technology to use local dent corn was expected to grow the 
motivation of community to develop household-scale businesses that have an effect to increase the economy of the Andaleh Village community.

Keywords: Dent Corn, Andaleh Village, Corn Nugget, Transition of Technology, Local Foods

\section{PENDAHULUAN}

Teknologi merupakan keseluruhan sarana untuk menyediakan barang-barang yang diperlukan bagi kelangsungan dan kenyamanan hidup manusia [1]. Salah satu tujuan penerapan teknologi dalam pengolahan pangan adalah untuk memanfaatkan bahan pangan alternatif yang sebelumnya tidak dimanfaatkan sebagai pangan dan untuk meningkatkan nilai tambah dari bahan pangan, baik melalui proses pengolahan, pengawetan, pengemasan, ataupun penyimpanan. Inovasi pangan merupakan suatu proses menciptakan produk pangan baru ataupun memperbaiki produk pangan yang sudah ada untuk meningkatkan nilai jualnya.

Kegiatan pengolahan pangan akan menghasilkan produk pangan yang baik jika disertai dengan praktik pengolahan pangan yang baik sesuai dengan Cara Produksi Pangan Olahan yang Baik (CPPOB) oleh pelaku pengolahan pangan itu sendiri. Praktik ini bertujuan untuk menjamin keamanan pangan dan kualitas pangan. Keamanan dan kualitas pangan dapat tercapai melalui praktik sanitasi dan higieni pangan. Sanitasi merupakan kegiatan atau upaya yang dilakukan untuk menciptakan kebersihan lingkungan, sedangkan higieni merupakan upaya untuk menjaga atau memelihara serta melindungi kebersihan subyek atau personal.
Komoditi bahan pangan yang banyak dibudidayakan oleh masyarakat di suatu wilayah menjadi salah satu perhatian yang diharapkan mampu memberikan nilai tambah ekonomi bagi masyarakat. Berbasis kepada pangan lokal ini diharapkan mampiu meningktkan perekonomian masyarakat dan dapat mewujudkan kemandirian pangan.

Kenagarian Andaleh terletak di Kecamatan Luak, Kabuaten Limapuluh Kota. Kenagarian ini memiliki jarak lebih kurang tiga kilometer dari ibukota kecamatan. Tanaman pangan lokal yang banyak dibudidayakan di Kenagarian Andaleh adalah jagung tipe jagung gigi kuda (Zea mays var. indentata). Jagung gigi kuda memiliki biji yang melekuk di bagian tengah atau bagian atas biji, sehingga berbentuk gigi. Jagung ini mengandung karbohidrat (pati) yang tinggi, bertekstur keras, dan biasanya hanya digunakan sebagai pakan ternak, khususnya ternak unggas.

Komposisi kimia jagung bermacammacam tergantung pada varietas jagung tersebut. [2] Secara umum, jagung dan jagung manis mempunyai kadungan gizi yang dapat dilihat pada Tabel 1. 
Tabel 1. Kandungan gizi jagung dan jagung manis (per 100 gr bahan)

\begin{tabular}{|l|c|c|}
\hline Zat gizi & $\begin{array}{c}\text { Jagung } \\
\text { biasa }\end{array}$ & $\begin{array}{c}\text { Jagung } \\
\text { manis }\end{array}$ \\
\hline Energi (cal) & 129 & 96.0 \\
\hline Protein (gr) & 4.1 & 3.5 \\
\hline Lemak (gr) & 1.3 & 1.0 \\
\hline Karbohidrat (gr) & 30.3 & 22.8 \\
\hline Kadar gula (\%) & 9 & 16 \\
\hline Kalsium (mg) & 5.0 & 3.0 \\
\hline Fosfor (mg) & 108.0 & 111 \\
\hline Besi (mg) & 1.1 & 0.7 \\
\hline Vitamin A (SI) & 117.0 & 400 \\
\hline Vitamin B (mg) & 0.18 & 0.15 \\
\hline Vitamin C (mg) & 9.0 & 12.0 \\
\hline Air (gr) & 63.5 & 72.7 \\
\hline
\end{tabular}

Jagung dapat diolah menjadi aneka makanan ringan, salah satunya adalah nugget jagung. Nugget merupakan suatu bentuk olahan daging yang diberi bumbu, dicampur dengan bahan pengikat kemudian dicetak menjadi bentuk tertentu dan dilumuri dengan tepung roti (coating) kemudian digoreng [3]. Nugget jagung dibuat dengan mencampurkan jagung bersama bahan baku utamanya yaitu daging ayam.

Kegiatan pengabdian kepada masyarakat merupakan kegiatan menerapkan hasil-hasil penelitian kepada masyarakat dan menyebarluaskan ilmu pengetahuan kepada masyarakat. Selain itu juga memperkenalkan beberapa teknologi pengolahan tepat guna dalam rangka meningkatkan nilai jual hasil pertanian rangkaian kegiatan ini bertujuan untuk meningkatkan pengetahuan masayarakat Nagari Andaleh Kecamatan Luak, tentang menjaga keamanan pangan serta pemanfaatan bahan pangan lokal, khususnya komoditi jagung ini melalui alih teknologi pengolahan menjadi nugget jagung. METODE PELAKSANAAN KEGIATAN

Mitra atau sasaran kegiatan pengabdian ini adalah kelompok PNPM Mitra Pelangi Galo Gandang, Kenagarian Andaleh, Kecamatan Luak, Kabupaten Limapuluh Kota. Tahap awal kegiatan pengabdian dilakukan dengan sosialisasi dan koordinasi dengan kelompok sasaran Kelompok Wanita Tani (KWT). Sosialisasi dan koordinasi dilakukan dengan menyusun rencana kerja, mengatur jadwal pelaksanaan, dan mengumpulkan permasalahan yang dihadapi masyarakat di lokasi pengabdian. Kegiatan pengabdian dilaksanakan dalam bentuk ceramah, diskusi, dan demonstrasi.

Kegiatan pertama adalah ceramah dan diskusi mengenai pentingnya dan cara-cara praktik higieni dan sanitasi dalam pengolahan pangan, meliputi sanitasi pekerja dan peralatan pengolahan pangan. Kegiatan berikutnya adalah demonstrasi tentang pengolahan nugget jagung sebagai upaya meningkatkan nilai jual jagung yang banyak dibudidayakan oleh masyarakat.

\section{HASIL DAN PEMBAHASAN}

\section{Sosialisasi dan koordinasi dengan kelompok sasaran}

Kegiatan sosialisasi dilakukan kepada kelompok sasaran bertujuan untuk mendapatkan informasi tentang potensi hasil pertanian di daerah Kenagarian Andaleh, serta menampung aspirasi kelompok masyarakat tentang permasalahan- 
permasalahan di bidang pangan atau kendala yang dihadapi dalam pengolahan produk pangan selama ini.

Kelompok masyarakat ini melaporkan bahwa jagung yang banyak dibudidayakan selama ini hanya dimanfaatkan sebagai pakan ternak dan belum dimanfaatkan sebagai bahan pangan. Selain itu, kelompok masyarakat ini juga melaporkan tentang keluhan umur simpan makanan yang singkat. Berdasarkan hal tersebut, diambil langkah untuk memberikan penyuluhan tentang praktik higieni dan sanitasi yang berhubungan dengan kemanan pangan dan umur simpan makanan, serta penyuluhan tentang alih teknologi pengolahan jagung menjadi nugget jagung.

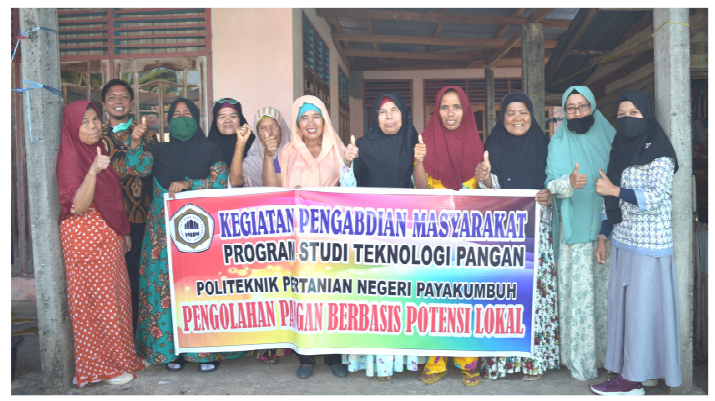

Gambar 1. Sosialisasi dan koordinasi kepada kelompok PNPM Mitra Pelangi Galo

Gandang, Kenagarian Andaleh, Kecamatan Luak, Kabupaten Limapuluh Kota

\section{Penyuluhan praktik sanitasi dan higieni personal dan peralatan}

Salah satu penyebab keracunan makanan yang sering dijumpai disebabkan karena tidak diperhatikannya kebersihan perorangan dan lingkungan dalam proses pengolahan makanan [4]. Penyuluhan sanitasi dan higieni bertujuan untuk mencegah kontaminasi silang, yaitu terjadinya transmisi bahaya biologis, fisik, kimia, dan kontaminan lainnya pada bahan makanan. Kelompok
PNPM Mitra Pelangi Galo Gandang diberikan penyuluhan tentang pentingnya dan cara menjaga kebersihan personal untuk menjaga kemanan pangan.

Menjaga kebersihan pekerja merupakan bagian dari kegiatan pengontrolan keamanan pangan. Cara menjaga kebersihan personal yang diberikan antara lain: mandi sebelum melakukan pengolahan pangan, membersihkan rambut dan menutupinya selama kegiatan pengolahan, membersihkan kuku, mencuci tangan dengan benar dan teratur, tidak menggunakan perhiasan seperti cincin dan gelang selama mengolah pangan, menggunakan alat pelindung diri (penutup kepala, masker, apron, dan sarung tangan), menutupi jika ada bagian tubuh yang luka, dan melaporkan keadaan kesehatan diri.

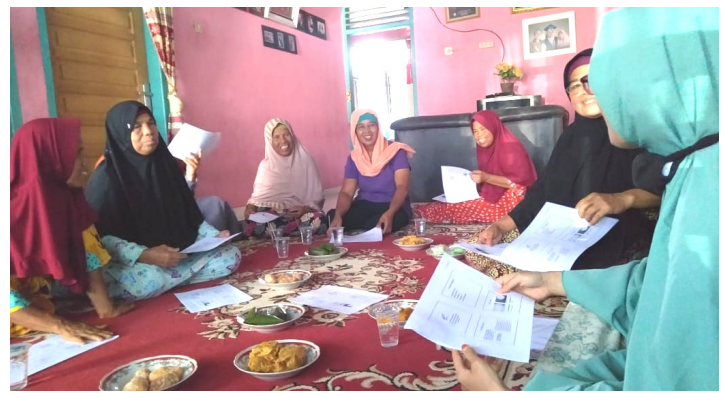

Gambar 2. Ceramah tentang pentingnya sanitasi pekerja dalam pengolahan pangan

Peralatan makanan merupakan hal yang tidak dapat dipisahkan dari prinsip higienisanitasi makanan dan minuman, sehingga peralatan makan harus dijaga kebersihannya, karena dengan menjaga kebersihan peralatan makan dapat mencegah terjadinya kontaminasi makanan [5]. Cara menjaga kebersihan peralatan yang diberikan antara lain: mencuci peralatan segera setelah pemakaian, mencuci dengan sabun dan air mengalir, mengeringkan peralatan setelah 
dicuci, dan menggunakan peralatan yang berbeda untuk jenis bahan baku yang berbeda.

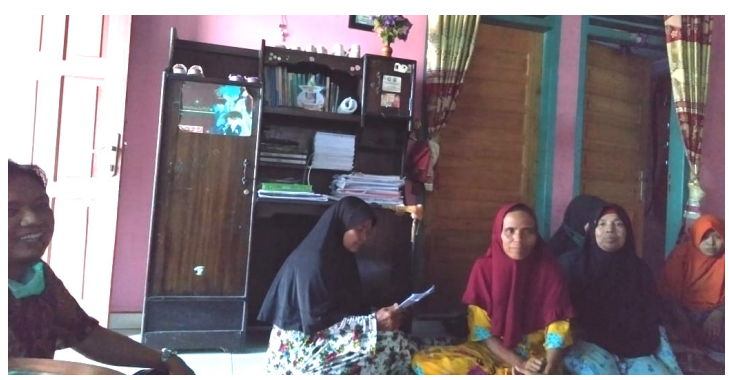

Gambar 3. Ceramah tentang pentingnya sanitasi peralatan dalam pengolahan pangan

Praktik pembuatan nugget jagung sebagai alih teknologi pengolahan jagung

Nugget adalah suatu bentuk produk olahan daging yang terbuat dari daging giling yang dicetak dalam bentuk potongan ampat persegi dan dilapisi tepung berbumbu (baterred and braded) [6]. Nugget merupakan makanan camilan ataupun lauk yang biasanya dibuat dari daging seperti daging ayam dan ikan serta dengan penambahan aneka bumbu dan sayuran. Jagung berpotensi dijadikan sebagai bahan campuran nugget karena sering dikonsumsi oleh masyarakat dan memiliki karbohidrat dan protein yang tinggi.

Nugget jagung dibuat dari campuran daging ayam dan jagung dengan perbandingan jumlah penambhaan jagung sebanyak 20\% dari berat daging ayam. Bahan penunjang yang digunakan adalah bawang putih, daun bawang, merica, garam, telur, tepung tapioka, tepung terigu, dan tepung maizena. Nugget dibuat dengan cara penghancuran bahan (daging ayam dan jagung), membuat adonan (pencampuran dengan bahan tambahan), pengukusan, pembentukan produk (pemotongan), pemaniran, dan penggorengan. Praktik sanitasi dan higieni yang dibahas sebelumnya dipraktikkan dalam kegiatan pengolahan nugget ini.

Nugget jagung mengandung komponen zat gizi serta non-gizi yang bermanfaat bagi tubuh, seperti karbohidrat, protein, lemak, vitamin, mineral, dan serat pangan. Selain itu juga diinformasikan tentang kandungan gizi nugget jagung yang dihasilkan. Syarat mutu nugget ayam menurut SNI 01-6683-2002, sebagai berikut:

\begin{tabular}{|c|c|}
\hline Jenis uji & Persyaratan \\
\hline $\begin{array}{c}\text { Keadaan } \\
\text { Aroma } \\
\text { Rasa } \\
\text { Tekstur }\end{array}$ & $\begin{array}{c}\text { Normal, sesuai label } \\
\text { Normal, sesuai label } \\
\text { Normal }\end{array}$ \\
\hline $\begin{array}{c}\text { Air, } \\
\% \text { b/b }\end{array}$ & Maks. 60 \\
\hline $\begin{array}{c}\text { Protein, } \\
\% \text { b/b }\end{array}$ & Min. 12 \\
\hline $\begin{array}{c}\text { Lemak, } \\
\% \text { b/b }\end{array}$ & Maks. 20 \\
\hline $\begin{array}{c}\text { Karbohidrat, } \\
\% \text { b/b }\end{array}$ & Maks. 25 \\
\hline $\begin{array}{c}\text { Kalsium } \\
\text { mg/100g }\end{array}$ & Maks 30 \\
\hline
\end{tabular}

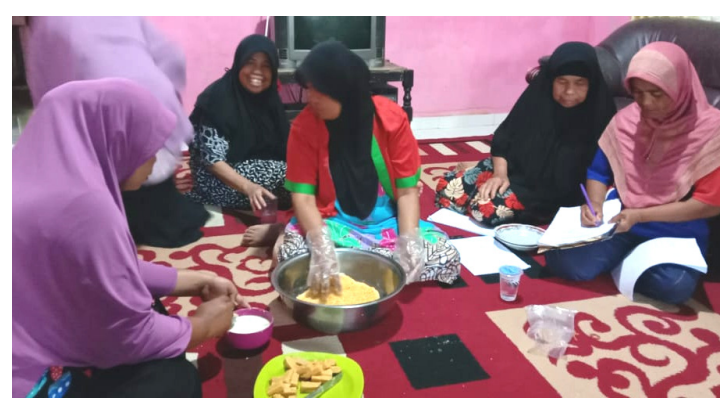

Gambar 4. Praktik pengolahan nugget jagung

\section{KESIMPULAN}

Kelompok masyarakat menyadari pentingnya penerapan sanitasi personal dan peralatan dalam melakukan pengolahan pangan, yang berpengaruh terhadap keamanan pangan. Alih teknologi 
pemanfaatan bahan pangan lokal jagung menjadi nugget jagung dapat memotivasi masyarakat untuk mengembangkan usaha skala rumah tangga yang berpengaruh pada peningkatan perekonomian masyarakat di Kenagarian Andaleh.

\section{SARAN}

Dengan kegiatan alih teknologi pada pengabdian ini diharapkan kedepannya mampu diaplikasikan dan menjadi produk olahan andalan masyarakat Nagari Andaleh sehingga menambah perekonomian masyarakatnya.

\section{UCAPAN TERIMAKASIH}

Ucapan terimakasih diucapkan kepada Politeknik Pertanian Negeri Payakumbuh, dimana kegiatan pengabdian kepada masyarakat ini terselenggara atas pendanaan dari Dana Isian Penggunaan Anggaran (DIPA) Politeknik Pertanian Negeri Payakumbuh Tahun Anggaran 2020. Terimakasih juga diucapkan kepada kelompok PNPM Mitra Pelangi Galo Gandang, Kenagarian Andaleh, Kecamatan Luak, Kabupaten Limapuluh Kota.

\section{REFERENSI}

[1] Kamus Besar Bahasa Indonesia. Diakses pada 29 November 2020.

[2] Wahyudi, Marman. 2006. Proses Pembuatan dan Analisis Mutu Yoghurt. Jurnal Buletin teknik Pertanian, Vol. 11 No. 1

[3] Yuanita I dan Silitonga L. 2014. Sifat kimia dan palatabilitas nugget ayam menggunakan jenis dan konsentrasi bahan pengisi yang berbeda. Jurnal Ilmu Hewani dan Tropika. 3 (1): 1-5

[4] Ningsih R. 2014. Penyuluhan hygiene sanitasi makanan dan minuman, serta kualitas makanan yang dijajakan pedagang di lingkungan SDN Kota Samarinda. Jurnal Kesehatan Masyarakat. 10 (1): 64-72

[5] Ma'unah NA dan. Ulfa L. 2020. Hubungan antara personal hygiene, fasilitas sanitasi dan teknik penyimpanan peralatan makan dengan kebersihan peralatan makan di kantin dan makanan jajanan. Jurnal untuk Masyarakat Sehat. 4 (2): 112-119

[6] Maghfiroh, I. 2000. Pengaruh penambahan bahan pengikat terhadap karaktristik nugget dari ikan patin (Pangasius hypothalamus). Skripsi. Program Studi Teknologi Hasil Perikanan. Fakultas Perikanan Institut Pertanian Bogor. Bogor. 